Case Reports in
Gastroenterology
Case Rep Gastroenterol 2021;15:276-281

DOI: 10.1159/000513156

Published online: March 4, 2021

(C) 2021 The Author(s)

Published by S. Karger AG, Basel www.karger.com/crg

This article is licensed under the Creative Commons Attribution-NonCommercial 4.0 International License (CC BY-NC) (http://www.karger.com/Services/OpenAccessLicense). Usage and distribution for commercial purposes requires written permission.

\title{
How Oral Specialists Can Help Diagnose and Manage Extra-Digestive Inflammatory Bowel Disease Complications
}

\author{
Charlotte Thomas ${ }^{\mathrm{a}, \mathrm{b}}$ Mylène Dimmock ${ }^{\mathrm{c}}$ \\ Cyrielle Gilletta de Saint-Joseph ${ }^{d}$ Béatrice Barres ${ }^{e} \quad$ Carle Paul $^{\mathrm{f}, \mathrm{g}}$ \\ Sarah Cousty ${ }^{b, c}$ Sara Laurencin-Dalicieux ${ }^{a, b}$

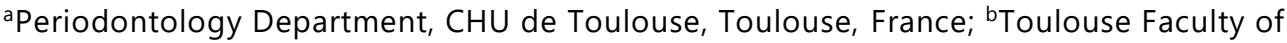 \\ Dental Medicine, Paul Sabatier University, Toulouse, France; 'Oral Surgery Department, \\ $\mathrm{CHU}$ de Toulouse, Toulouse, France; ${ }^{\mathrm{C}}$ Gastroenterology and Pancreatology Department, \\ $\mathrm{CHU}$ de Toulouse, Toulouse, France; ePathology Department, Institut Claudius Regaud,

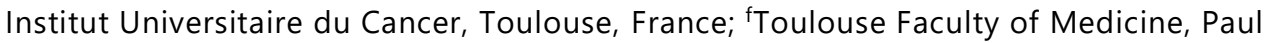 \\ Sabatier University, Toulouse, France; 9Dermatology Department, Larrey Hospital, CHU de \\ Toulouse, Toulouse, France
}

\section{Keywords}

Inflammatory bowel disease · Extra-digestive manifestations · Oral manifestation · Gingival enlargement $\cdot$ Concept map

\begin{abstract}
Identification of extra-digestive manifestations of inflammatory bowel disease (IBD) is essential. The oral cavity is a preferential site in which gingival enlargement may be one of these manifestations. We present, in this article, two original cases and a concept map that highlights the need for a close collaboration between the dental surgeon or oral specialist, the dermatologist, and the gastroenterologist. In the first case, the strictly local management of a systemic IBD oral complication, can relieve and answer the patient's complaint without modifying or disrupting the systemic treatment already implemented by the gastroenterologists. In the second case, the dental surgeon's diagnosis of gingival enlargement turns out to be the inaugural manifestation of Crohn's disease and allows early treatment of the intestinal pathology.
\end{abstract}

\begin{tabular}{ll}
\hline & Sara Laurencin-Dalicieux \\
& Periodontology Department \\
Toulouse's Faculty of Dental Medicine & 3 chemin des Maraîchers, FR-31062 Toulouse Cedex 9 (France) \\
laurencin.s@chu-toulouse.fr
\end{tabular}




\section{Case Reports in Gastroenterology}

Case Rep Gastroenterol 2021;15:276-281 DOI: $10.1159 / 000513156$

c) 2021 The Author(s). Published by S. Karger AG, Basel www.karger.com/crg

Thomas et al.: IBD Extra-Digestive Oral Complications

These two cases illustrate the close link between the oral cavity and IBD. Knowledge and multidisciplinary management of these manifestations such as proposed in the concept map are essential for clinicians for the early diagnosis and the improvement of the oral and general quality of life of patients suffering from IBD.

\section{Introduction}

Gingival enlargement is a common oral manifestation that has multiple aetiologies among them poor dental plaque control, hormones, medications, and chronic systemic diseases [1]. It can also be associated with pain, ulcerations, tooth migration and mobility, chewing and speech disorders and have unattractive, aesthetic consequences. This can highly impair the patient's well-being and alter their quality of life. Also, identifying the aetiology and establishing the correct diagnosis allows setting up an appropriate therapy and limits the risk of recurrence. Patients with chronic inflammatory bowel disease (IBD), Crohn's disease being the most common, can be subject to extra-digestive, oral, manifestations. These manifestations are generally polymorphic: aphthous, gingival hypertrophy, cobblestone patterns, ulcerations but also pyostomatitis vegetans and cheilitis [2]. They should however not be neglected because they can be either associated with the pathology itself or the consequences of its treatment. They can also be inaugural of the disease or reflect a relapse of the disease at the time of treatment.

We report here through two different clinical cases, the course of care and strictly oral management of such gingival enlargements and propose a concept map as a clinician's guide.

\section{Case Report}

Patient 1, a 42-year-old female, was referred to us by the gastroenterologists for intense gingival pain and cheilitis evolving for a few weeks (Fig. 1a, b). She was under treatment for Crohn's disease by an immunomodulatory anti-TNF $\alpha$ drug, infliximab (REMICADE ${ }^{\circledR}$ ), since 2001.

Patient 2, a 25-year-old male, was referred to us by the orthodontists for a recurring gingival enlargement associated with severe tooth migration evolving for several years (Fig. 1c). He had a family history of Crohn's disease. Oral and facial clinical exams also showed signs of labial hypertrophy with cheilitis and a cobblestone type of hypertrophy on the inner side of the cheeks (Fig. 1d).

Gingival biopsies were performed on both patients. Anatomopathological examination revealed a squamous papillomatous epithelium without cytonuclear atypia resting on an essentially lympho-plasmocytic inflammatory chorion. Giganto-cellular granulomas were found in both cases, without the presence of caseous necrosis. These typical forms of granulomas can be either isolated in the oral cavity or found in cases of systemic diseases such as IBD (Fig. 2).

After having the stability of her Crohn's disease reassessed by the gastroenterologist, topical dermocorticoids (Clobetasol, Dermoval ${ }^{\circledR}$ ) were prescribed for patient 1 . After 15 days of bi-daily application, complete clinical and symptomatic improvement was observed (Fig. 3a).

For patient 2, a complete endoscopic examination was carried out, revealing no signs of IBD lesions in the digestive tract. A local gingivectomy was carried out in order to remove the

\section{Karger'=}




\section{Case Reports in Gastroenterology}

\begin{tabular}{l|l}
\hline Case Rep Gastroenterol 2021;15:276-281 \\
\hline DOI: 10.1159/000513156 & $\begin{array}{l}\text { @ 2021 The Author(s). Published by S. Karger AG, Basel } \\
\text { www.karger.com/crg }\end{array}$ \\
\hline
\end{tabular}

Thomas et al.: IBD Extra-Digestive Oral Complications

gingival overgrowth. Also, given the overall general clinical picture, this oral manifestation being considered as inaugural of the pathology, a preventive treatment with adalimumab (HUMIRA ${ }^{\circledR}$ ) was introduced after a multidisciplinary meeting. No gingival recurrences were observed during the 18-month follow-up (Fig. 3b). However, an annual follow-up of the digestive tract was set up in order to monitor the appearance of intestinal symptoms since they can appear several years after the oral lesions.

\section{Discussion}

IBDs are characterized by chronic intestinal inflammation evolving into a variable course of flare-ups and remission [3]. Although the aetiology is still imperfectly known today, the main hypothesis is an inadequate intestinal immune response to bacteria in the commensal flora, probably triggered by environmental factors associated with genetic predisposition. The most common symptoms are pain, abdominal cramps, diarrhoea, rectal bleeding, weight loss, faintness, tiredness. 50\% of IBD patients develop oral lesions with a wide variety of clinical forms such as linear fissures, white reticular tags, cobblestone mucosal patterns (pathognomonic of Crohn's disease), gingival enlargement and labial swelling [2, 4]. They may be specific to the intestinal pathology (inaugural, at the same time or after the appearance of gastrointestinal symptoms) or reactive, non-specific consequences of drug treatments and nutritional deficiencies due to malabsorption and malnutrition [5]. They may also be early signs of therapeutic escape or disease relapse. Management of these patients is multidisciplinary, it requires a close collaboration between dental surgeons or oral specialists, dermatologists, and gastroenterologists. For this, we propose a clinician's guide in the form of a concept map (Fig. 4). In a known IBD context, the appearance of oral lesions should lead to address to gastroenterologists to reassess the digestive pathology. The oral biopsy will confirm if the lesion is related to the digestive pathology or its treatment. If so, treatment of the oral manifestation will start with the application of topical steroids such as clobetasol (Dermoval ${ }^{\circledR}$ ) several times a day for at least 15 days. If insufficient, systemic steroids may be used at a dose of 0.8 $\mathrm{mg} / \mathrm{kg} /$ day for 1 month [6]. In addition, in some cases, local surgical management by gingivectomy is necessary since gingival overgrowth renders oral hygiene difficult, aggravating the oral manifestation. In most cases, complementary examinations (other biopsies, biological analyses, radiological examinations, digestive tract extension check-ups) are to be carried out in order to eliminate differential diagnoses. Indeed, there are many chronic pathologies with granulomatous lesions that may have as an oral expression gingival enlargement (Wegener's disease, sarcoidosis, orofacial granulomatosis, tuberculosis, or fungal infections) [7-10]. Establishing the correct diagnosis represents a major impact in the management of not only IBD but also the oral lesions. Close collaboration between oral specialists, dermatologists, and gastroenterologists is essential in order to respond to patients' complaints, prevent non-aggravation of the intestinal state, and improve overall quality of life.

\section{Statement of Ethics}

All patients in this study have given their written informed consent to publish their case (including publication of images).

\section{Karger'=}


Case Reports in
Gastroenterology

Case Rep Gastroenterol 2021;15:276-281

DOI: 10.1159/000513156

(c) 2021 The Author(s). Published by S. Karger AG, Basel www.karger.com/crg

Thomas et al.: IBD Extra-Digestive Oral Complications

\section{Conflict of Interest Statement}

The authors have no conflicts of interest to declare.

\section{Funding Sources}

The authors received no funds for this research.

\section{Author Contributions}

Charlotte Thomas and Mylène Dimmock contributed substantially to the design of the work and to drafting the work.

Cyrielle Gilletta contributed substantially to the interpretation of the data of the work and revised it critically from the gastroenterological point of view.

Béatrice Barres contributed to the acquisition and analysis of the anatomopathological samples and revised the work accordingly.

Carle Paul and Sarah Cousty contributed substantially to the interpretation of the data of the work and revised it critically from the dermatological point of view.

Sara Laurencin-Dalicieux contributed substantially to the conception and design of the work, interpretation of the data, and drafting of the manuscript.

All authors approved of the final version of this case report and agree to be accountable for all aspects of the work.

\section{References}

1 Agrawal AA. Gingival enlargements: differential diagnosis and review of literature. World J Clin Cases. 2015 Sep;3(9):779-88.

2 Lankarani KB, Sivandzadeh GR, Hassanpour S. Oral manifestation in inflammatory bowel disease: a review. World J Gastroenterol. 2013 Dec;19(46):8571-9.

3 Sartor RB. Mechanisms of disease: pathogenesis of Crohn's disease and ulcerative colitis. Nat Clin Pract Gastroenterol Hepatol. 2006 Jul;3(7):390-407.

4 Mortada I, Leone A, Gerges Geagea A, Mortada R, Matar C, Rizzo M, et al. Oral manifestations of inflammatory bowel disease. J Biol Regul Homeost Agents. 2017 Jul-Sep;31(3):817-21.

5 Muhvić-Urek M, Tomac-Stojmenović M, Mijandrušić-Sinčić B. Oral pathology in inflammatory bowel disease. World J Gastroenterol. 2016 Jul 7;22(25):5655-67.

6 Dimmock M, Mendes LC, Albluwi S, Paul C, Thomas C, Laurencin S, et al. An oral manifestation of IBD: pyostomatitis vegetant, about two cases. J Stomatol Oral Maxillofac Surg. 2019 Sep;120(4):375-7.

7 Alawi F. An update on granulomatous diseases of the oral tissues. Dent Clin North Am. 2013 Oct;57(4):65771.

8 Suresh L, Radfar L. Oral sarcoidosis : a review of literature. Oral Dis. 2005 May;11(3):138-45.

9 Stewart C, Cohen D, Bhattacharyya I, Scheitler L, Riley S, Calamia K, et al. Oral manifestations of Wegener's granulomatosis: a report of three cases and a literature review. J Am Dent Assoc. 2007 Mar;138(3):338-48.

10 Grave B, Mccullough M, Wiesenfeld D. Orofacial granulomatosis - a 20-year review. Oral Dis. 2009 Jan;15(1):46-51. 
Case Reports in Gastroenterology
Case Rep Gastroenterol 2021;15:276-281

DOI: $10.1159 / 000513156$

(c) 2021 The Author(s). Published by S. Karger AG, Basel www.karger.com/crg

Thomas et al.: IBD Extra-Digestive Oral Complications
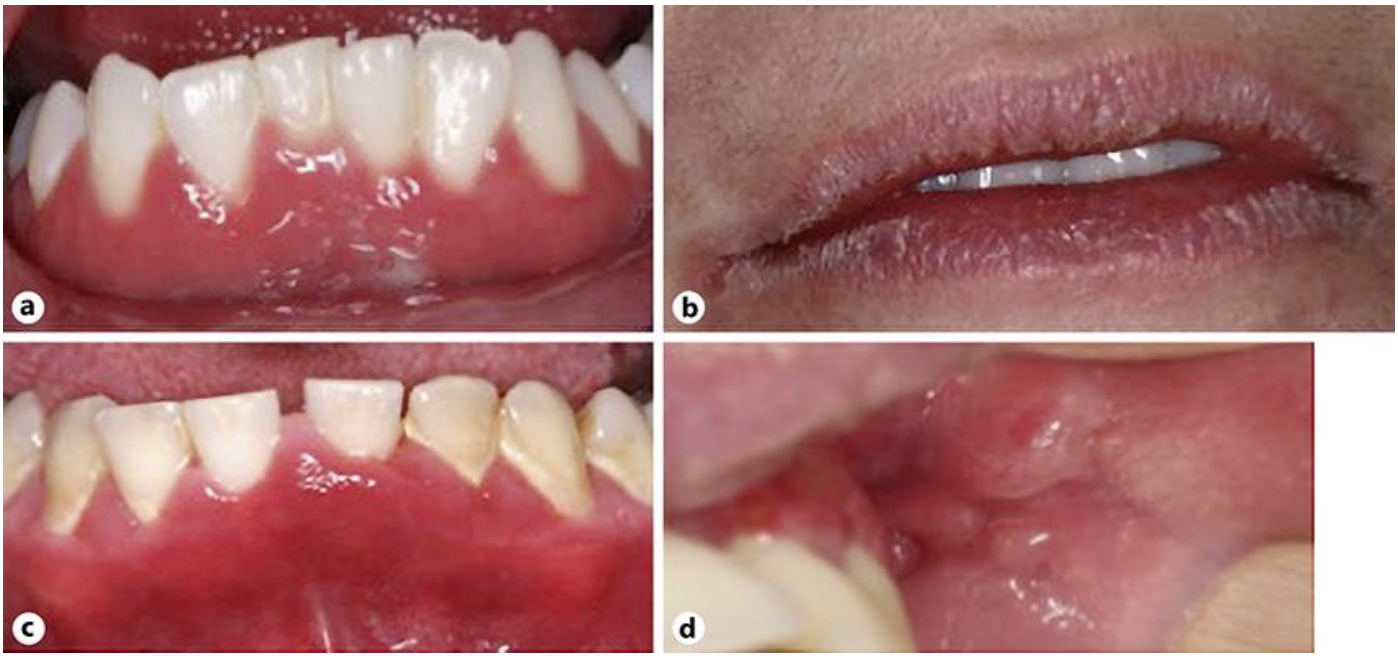

Fig. 1. a Gingival enlargement in patient 1. b Cheilitis in patient 1. c Gingival enlargement in patient 2. d Cobblestone lesion on the inner side of the cheek in patient 2 .

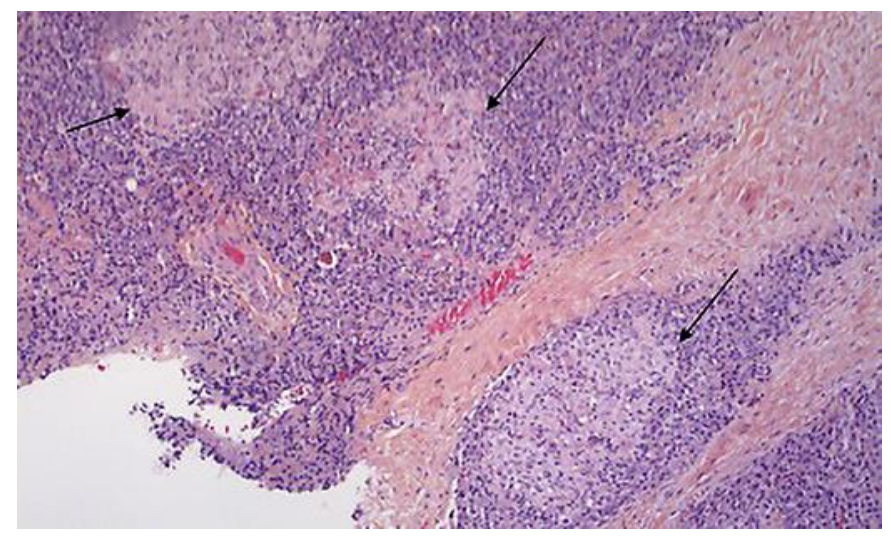

Fig. 2. Histopathological sections of gingival biopsies stained with haematoxylin-eosin revealing the presence of granulomas $(\times 10)$.
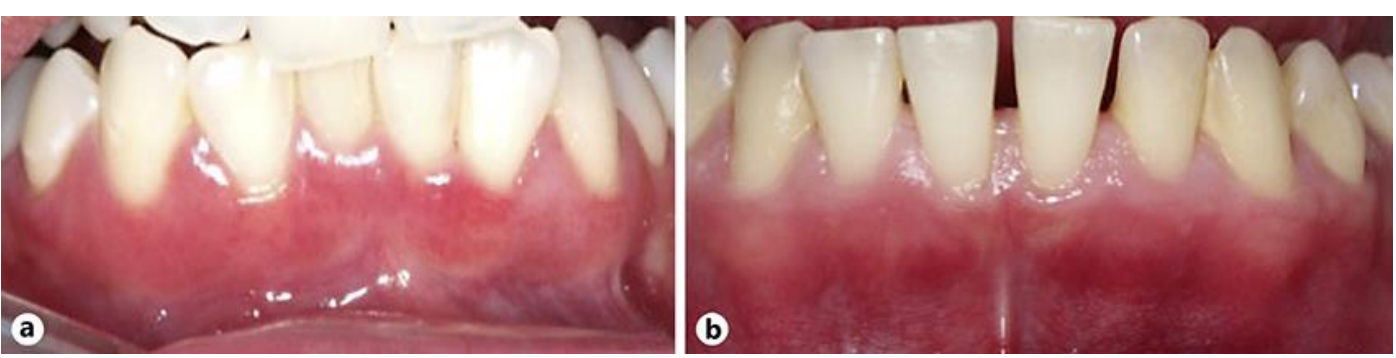

Fig. 3. a Clinical situation after 15 days of local topical corticosteroid treatment (patient 1). b clinical situation, 18 months after surgical treatment by gingivectomy (patient 2).

\section{Karger'}


Case Reports in Gastroenterology
Case Rep Gastroenterol 2021;15:276-281

DOI: $10.1159 / 000513156$

(c) 2021 The Author(s). Published by S. Karger AG, Basel www.karger.com/crg

Thomas et al.: IBD Extra-Digestive Oral Complications

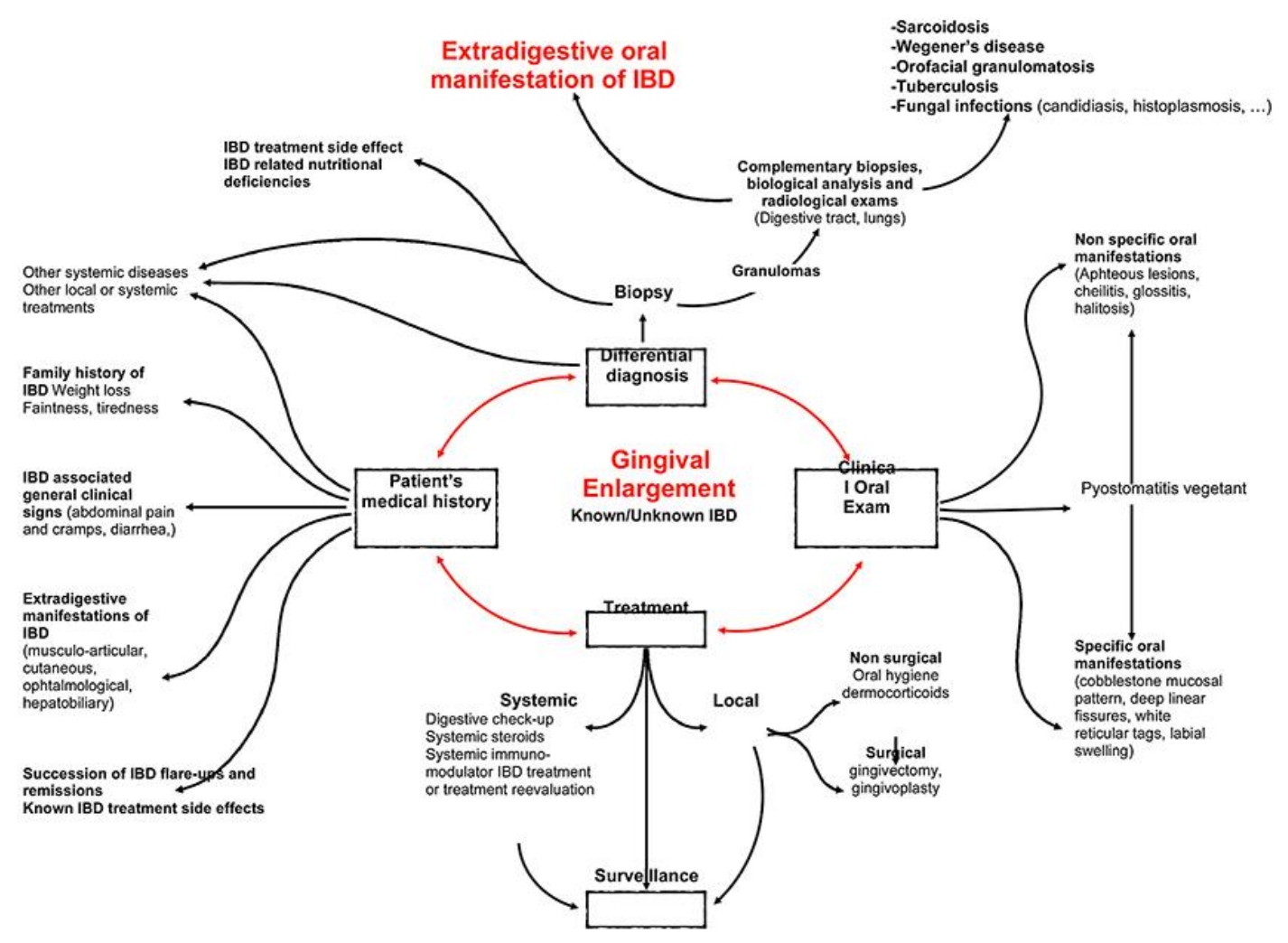

Fig. 4. Gingival enlargement and IBD concept map and clinician's guide. 